\title{
Prediction and Evaluation of Urine and Urinary Nitrogen and Mineral Excretion from Dairy Cattle
}

\author{
T. D. Nennich, ${ }^{* 1}$ J. H. Harrison, ${ }^{\star 2}$ L. M. VanWieringen, ${ }^{*}$ N. R. St-Pierre, $\dagger$ \\ R. L. Kincaid, $¥$ M. A.Wattiaux,§ D. L. Davidson, ${ }^{\star}$ and E. Block\| \\ ${ }^{*}$ Puyallup Research and Extension Center, Washington State University, Puyallup 98371 \\ †Department of Animal Sciences, The Ohio State University, Columbus 43210 \\ ‡Department of Animal Sciences, Washington State University, Pullman 99163 \\ $\S$ Department of Dairy Science, University of Wisconsin, Madison 53706 \\ ||Church \& Dwight Co. Inc., Princeton, NJ 08543
}

\begin{abstract}
Urine excretion is a substantial factor in the amount of manure that needs to be managed, and urinary $\mathrm{N}$ can contribute to ammonia volatilization. Development and validation of prediction equations focusing on dietary factors to decrease urine and urinary nutrient excretion will provide information for managing urine and feces separately or for other future technologies. The objective of this study was to develop equations for prediction of urine excretion and excretion of urinary $\mathrm{N}, \mathrm{Na}$, and $\mathrm{K}$ and to evaluate both new and previously published prediction equations for estimation of urine and urinary nutrient excretion from lactating dairy cows. Data sets from metabolism studies conducted at Washington State University were compiled and evaluated for excretion of minerals. Urine excretion averaged $24.1 \mathrm{~kg} / \mathrm{d}$ and urinary nitrogen excretion ranged from 63 to $499 \mathrm{~g} / \mathrm{d}$ in the calibration data set. Regression equations were developed to predict urine excretion, urinary $\mathrm{N}$ excretion, and urinary $\mathrm{Na}$ and $\mathrm{K}$ excretion. Predictors used in the regression equations included milk yield, body weight, dietary crude protein percentage, milk urea nitrogen, and nutrient intakes. Previously published prediction equations were evaluated using data sets from Washington State University and the University of Wisconsin. Mean and linear biases were evaluated by determining the regression of residuals on predicted values. Evaluation and validation of prediction equations are important to develop equations that will more accurately estimate urine and urinary nitrogen excretion from lactating dairy cows.
\end{abstract}

Key words: urine, urinary nitrogen, sodium, potassium

\footnotetext{
Received December 22, 2004.

Accepted August 26, 2005.

${ }^{1}$ Current address: Department of Animal Science, Stephenville Research and Extension Center, Texas A\&M University, Stephenville, TX 76401.

${ }^{2}$ Corresponding author: jhharrison@wsu.edu
}

\section{INTRODUCTION}

The amount of urine excreted greatly affects total manure excretion from lactating dairy cows because urine excretion accounts for approximately one-third of total manure excretion on a weight basis (NRC, 2001). Urine excretion has been directly linked to intakes of $\mathrm{Na}$ and K (Fisher et al., 1994; Bannink et al., 1999) and to $\mathrm{N}$ intake (Bannink et al., 1999). Excretion of urine can potentially be reduced by supplying nutrients in levels that meet, but do not exceed, animal requirements. Increased urine excretion results in requirements for larger manure storage facilities and may even require additional nutrient export or land for application.

Urinary excretion is the main method of homeostatic regulation for $\mathrm{Na}$ and $\mathrm{K}$, thus intake of these minerals will directly affect $\mathrm{Na}$ and $\mathrm{K}$ excretion (Miller, 1975). In 2001, the Natural Resources Conservation Service standard for nutrient management planning (NRCS, 2001) stated that nutrient budgets should be established for N, P, and K. Although K has not been directly linked to environmental problems, excess field application of $\mathrm{K}$ results in a build up of soil $\mathrm{K}$ and must be considered by livestock producers during development of nutrient management plans. Greater soil concentrations of $\mathrm{K}$ can lead to higher concentrations of $\mathrm{K}$ in forages because grasses are luxury consumers of $\mathrm{K}$ (Harrison et al., 2003). High concentrations of $K$ in forages will lead to greater intakes of $\mathrm{K}$, which is a concern for periparturient dairy cows (NRC, 2001).

Prediction equations provide a means of estimating values that are difficult to measure on dairy operations and provide information to assist with the management of manure and nutrients. Evaluation of prediction equations is necessary to determine the accuracy of equations for animals with various housing and dietary situations. Determining the usefulness of previously published equations and development of equations that more accurately estimate urinary excretion will provide 
opportunities to continue to refine management strategies on dairy operations.

Nitrogen excretion is an environmental concern because of its relationship to ammonia volatilization and the potential movement of $\mathrm{N}$ to surface or groundwater. Equations that demonstrate relationships between the amount of $\mathrm{N}$ excreted in urine and factors affecting excretion are beneficial for selecting management strategies to reduce urinary $\mathrm{N}$ excretion. Previously published prediction equations have directly linked excretion of urinary $\mathrm{N}$ with MUN concentrations in dairy cattle (Jonker et al., 1998; Kauffman and St-Pierre, 2001; Kohn et al., 2002). Additional equations can further refine these relationships and provide additional options for estimating urinary excretion.

Innovations in management techniques are continually being explored to decrease risks of nutrients leaving livestock operations through air or water. An example of a management strategy designed to decrease ammonia volatilization is the separation of urine and feces in animal housing facilities. Development of new management strategies that focus specifically on urine management requires information to better estimate urine excretion on dairy operations and to gain a better understanding of factors affecting urine and urinary nutrient excretion. The main objectives of this study were: 1) to develop new equations to predict excretion of urine, urinary $\mathrm{N}$, urinary $\mathrm{Na}$, and urinary $\mathrm{K} ; 2$ ) to evaluate newly developed urine and urinary $\mathrm{N}$ excretion equations; and 3) to evaluate previously published equations developed to predict excretion of urine, urinary N, and urinary minerals. During the development of prediction equations, an effort was made to include equations for use on commercial dairy operations and to gain a better understanding of dietary and metabolic factors affecting excretion.

\section{MATERIALS AND METHODS}

Data sets from Washington State University were combined and used for estimations of urinary excretion from dairy cattle (Table 1). The overall data set only included records from multiparous lactating cows. Data were divided into 2 groups including lactating cows (LACT) and a subset of lactating cows for which mineral intake and excretion data were available (MINERAL). The LACT data set (372 cow-periods from Latin square experiments) included lactating Holstein cows. The MINERAL subset (115 cow-periods) included cows from the LACT data set for which intakes and excretion of minerals were known. The cows in the MINERAL subset were selected in an effort to incorporate cow-periods from a variety of feeding trials and an assortment of dietary treatments. Intakes of minerals were deter- mined through analyses of both feed and orts, thus animals were only included in the MINERAL subset if samples were available for mineral analyses of feed, orts, urine, and feces.

The LACT data set included observations from 16 individual feeding studies. Feeding studies were originally intended to evaluate nutritional hypothesis and were not designed specifically for development of excretion prediction equations. Variations in dietary ingredients, milk production, and DIM increased the errors associated with development of regression equations.

The independent variables included in the LACT data set were BW, DIM, DMI, milk yield (MILK), MUN, milk fat (MF), and milk protein (Table 2). The units associated with the independent variables were $\mathrm{kg} / \mathrm{ani}$ mal for BW, kg/d for DMI and MILK, mg/dL for MUN (which was determined by colorimetry), and MF and milk protein percentages (Table 2). Milk CP values in the data set were converted to percent milk true protein (MTP) values using a conversion factor of 0.9345 (Mackle et al., 1999). Other dietary characteristics and chemical compositions evaluated as prediction factors for equations included $\mathrm{N}$ intake (NI) in $\mathrm{g} / \mathrm{d}$, and dietary concentrations of CP and NDF. The supply of RDP (g/ d) was determined for each animal by entering data from each individual cow-period into the 2001 Dairy NRC model. Dependent variables included in the LACT data set included urine excretion, $\mathrm{kg} / \mathrm{d}$, and urinary $\mathrm{N}$ excretion, $\mathrm{g} / \mathrm{d}\left(\mathbf{U}_{\mathbf{N}}\right)$. The LACT data set was used to develop equations that did not require mineral data to increase the number of cows used in the development of the regression equations. The MINERAL subset was only used when mineral intake or excretion data were included in the equation. The MINERAL subset included the same variables as the LACT data set and included the following independent variables: $\mathrm{Na}$ intake (NaI, g/d), K intake (KI, g/d), urinary Na concentration (\%), and urinary $\mathrm{K}$ concentration (\%). The $\mathrm{DCAD}$ was determined using the following equation: $(\mathrm{Na}+\mathrm{K})-(\mathrm{S}+\mathrm{Cl})$. The MINERAL subset also included the dependent variables of urinary $\mathrm{Na}$ excretion $\left(\mathbf{U}_{\mathbf{N a}}\right.$, $\mathrm{g} / \mathrm{d})$, and urinary $\mathrm{K}$ excretion $\left(\mathbf{U}_{\mathbf{K}}, \mathrm{g} / \mathrm{d}\right)$.

Diets fed during the metabolism trials included a wide variety of protein supplements and forage types. Forages included corn silage, grass silage, alfalfa silage, and grass hay. The remainder of the diets included various grains, by-product feeds, and mineral supplements. Cows in these trials were fed ad libitum.

Equations given for each parameter included residual standard error (SE) and interstudy SE. Equations with lower SE are expected to provide a more precise estimation of excretion and should be used when values for the input variables are available. 
Table 1. Experiments included in the data sets used for development of urine (LACT) and urinary mineral (MINERAL) excretion equations

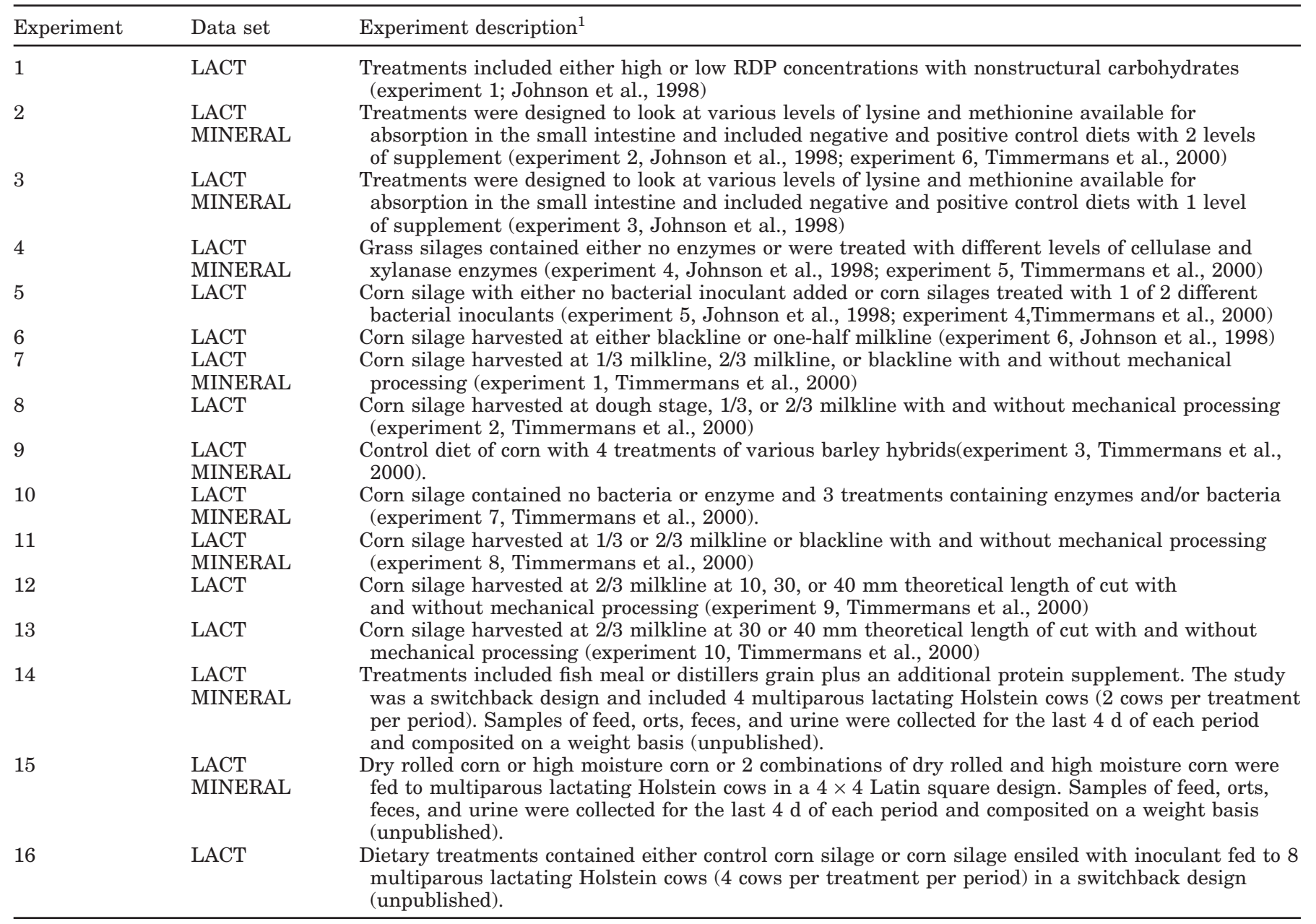

${ }^{1}$ Experiments 14, 15, and 16 were conducted at Washington State University using protocols similar to those for experiments 1 to 13.

Evaluations of previously published prediction equations for estimating urine excretion and $\mathrm{U}_{\mathrm{N}}$ were done using both the LACT data set and the VALIDATE data set. The VALIDATE data set included 48 observations of multiparous lactating Holstein cows from a study conducted by Wattiaux and Karg (2004). Animal characteristics for the VALIDATE data set are given in Table 2. The VALIDATE data set was also used to evaluate new equations developed using the LACT data set when the necessary variables were available in the VALIDATE data set.

Evaluation of previously published prediction equations that included mineral intakes or dietary mineral concentrations as either dependent or independent variables were evaluated with the MINERAL subset. These equations could not be evaluated with either the LACT or VALIDATE data sets because mineral data were not available for cows in these data sets. The unavailability of mineral data also precluded the evalu- ation of new equations developed using the MINERAL data set.

\section{Sample Collection and Analysis}

Total collection metabolism studies (16 studies) conducted at Washington State University included multiparous lactating cows (372 cow-periods). Mineral data were available for a group of these cows (115 cow-periods) included in the MINERAL subset. Feeding, sample collection, and sample analyses were conducted by methods outlined by Johnson et al. (1998) and Timmermans et al. (2000). Studies from the University of Wisconsin that were included in the VALIDATE data set included 48 observations from multiparous lactating cows. Descriptions of feeding, sampling, and collections were summarized by Wattiaux and Karg (2004).

Mineral analyses were conducted on TMR, orts, feces, and urine samples for cows in the MINERAL subset. 
NENNICH ET AL.

Table 2. Animal and production characteristics for the data sets used for development of prediction equations. Characteristics are included for data sets with all lactating cows (LACT), lactating cows for which mineral data was available (MINERAL), and cows in the validation data set (VALIDATE)

\begin{tabular}{|c|c|c|c|c|c|}
\hline Item & $\mathrm{n}$ & Mean & Minimum & Maximum & SD \\
\hline \multicolumn{6}{|l|}{ LACT data set } \\
\hline BW, kg & 372 & 629 & 437 & 800 & 64.6 \\
\hline DIM & 371 & 154 & 13 & 488 & 93.2 \\
\hline Milk, kg/d & 372 & 32.7 & 1.4 & 86.1 & 11.3 \\
\hline DMI, kg/d & 372 & 22.2 & 6.8 & 32.9 & 3.99 \\
\hline Milk fat, \% & 372 & 3.62 & 2.25 & 6.42 & 0.68 \\
\hline Milk protein, \% & 372 & 2.94 & 1.61 & 4.47 & 0.32 \\
\hline Dietary CP, \% & 372 & 175.8 & 128.9 & 243.8 & 18.7 \\
\hline MUN, mg/dL & 372 & 13.3 & 6.0 & 27.0 & 3.48 \\
\hline \multicolumn{6}{|c|}{ MINERAL data set } \\
\hline $\mathrm{BW}, \mathrm{kg}$ & 115 & 615 & 437 & 758 & 68 \\
\hline DIM & 115 & 145 & 16 & 356 & 73.0 \\
\hline Milk, kg/d & 115 & 34.1 & 3.8 & 86.1 & 13.8 \\
\hline DMI, kg/d & 115 & 21.5 & 10.5 & 31.6 & 4.28 \\
\hline Milk fat, \% & 115 & 3.69 & 2.47 & 6.42 & 0.67 \\
\hline Milk protein, $\%$ & 115 & 2.93 & 2.15 & 4.47 & 0.32 \\
\hline Dietary Na, \% & 115 & 0.66 & 0.28 & 1.15 & 0.20 \\
\hline Dietary K, \% & 115 & 1.36 & 0.58 & 1.86 & 0.23 \\
\hline Dietary Cl, \% & 115 & 0.42 & 0.25 & 0.60 & 0.09 \\
\hline Dietary S, \% & 115 & 0.26 & 0.14 & 0.42 & 0.05 \\
\hline $\mathrm{DCAD}, \mathrm{mEq} / \mathrm{kg}$ & 115 & 36.0 & 20.7 & 55.0 & 7.9 \\
\hline \multicolumn{6}{|c|}{ VALIDATE data set } \\
\hline BW, kg & 48 & 655 & 542 & 764 & 57.9 \\
\hline DIM & 48 & 83 & - & - & - \\
\hline Milk, kg/d & 48 & 41.2 & 22.9 & 53.3 & 6.0 \\
\hline DMI, kg/d & 48 & 23.5 & 14.5 & 31.9 & 3.9 \\
\hline Milk fat, \% & 48 & 2.83 & 1.45 & 4.84 & 1.45 \\
\hline Milk protein, \% & 48 & 2.78 & 2.26 & 3.32 & 0.25 \\
\hline Dietary CP, \% & 48 & 17.2 & 16.3 & 18.1 & 0.6 \\
\hline MUN, mg/dL & 48 & 11.9 & 7.7 & 15.5 & 2.08 \\
\hline
\end{tabular}

Minerals in feeds, orts, and feces were analyzed by the University of Nebraska Soil and Plant Analytical Laboratory (Lincoln, NE) via x-ray fluorescence spectrophotometry, and urine minerals were analyzed by Dairyland Laboratories (Arcadia, WI) using an inductively coupled plasma emission spectrophotometer. Samples were analyzed for various minerals including $\mathrm{Ca}, \mathrm{Cl}, \mathrm{K}, \mathrm{Mg}, \mathrm{Mn}, \mathrm{Na}, \mathrm{P}$, and $\mathrm{S}$. Mineral analyses were not conducted on milk samples. Therefore, milk mineral contents were assumed equivalent to values outlined in the 2001 Dairy NRC. Milk Na and K were estimated at 0.63 and $1.5 \mathrm{~g} / \mathrm{kg}$ of milk, respectively (NRC, 2001).

\section{Statistical Analyses}

Regression analyses were performed using PROC MIXED of SAS (SAS Institute, 1999) with the discrete effect of study included as a random variable (St-Pierre, 2001). Equations were developed by running multiple iterations in MIXED and removing the least significant effect at each iteration. For the LACT data set, variables were kept if $P<0.10$ because the number of observations were greater than 200 . Variables were kept if $P<0.25$ for the MINERAL subset due to the fewer number of observations (less than 200) available in the subset. Significant variables were compared by determining the errors for future predictions and selecting the independent variable that resulted in the least prediction error. Adjusted observations were calculated for graphing purposes by adding the residual from each individual observation to the predicted value of the study regression (St-Pierre, 2001).

Equations were evaluated by regressing residuals (predicted values subtracted from observed values) on the predicted values (St-Pierre, 2003). Predicted values were centered by subtracting the mean of all predicted values from each prediction. This makes the slope and intercept estimates in the regression orthogonal and, thus, independent. Mean biases were assessed using the intercepts of the regression equations and the slopes of the regression equations were used to determine the presence of linear biases.

\section{RESULTS AND DISCUSSION}

\section{Urine Excretion}

Urine excretion in the LACT data set averaged 24.1 $\mathrm{kg} / \mathrm{d}$ and accounted for $35.4 \%$ of total manure excretion on a weight basis (Table 3). According to the ASAE 
Table 3. Average excretion values for animals in the data sets of lactating cows (LACT), lactating cows for which mineral data was available (MINERAL), and for the validation data set (VALIDATE)

\begin{tabular}{lrrrrr}
\hline Item & $\mathrm{n}$ & Mean & Minimum & Maximum & SD \\
\hline LACT data set & & & & & \\
$\quad$ Urine, kg/d & 372 & 24.1 & 11.6 & 58.7 & 7.1 \\
Urinary N, g/d & 372 & 221.7 & 63.0 & 498.6 & 65.7 \\
MINERAL data set & & & & & \\
Urine, kg/d & 115 & 24.8 & 11.7 & 57.4 & 7.7 \\
Urinary N, g/d & 115 & 210.5 & 93.4 & 418.5 & 55.1 \\
Urinary K, g/d & 76 & 160.8 & 53.8 & 366.7 & 33.9 \\
Urinary Na, g/d & 76 & 84.8 & 22.0 & 161.6 & 8.3 \\
VALIDATE data set & & & & & 38.2 \\
Urine, kg/d & 48 & 29.0 & 17.1 & 320.0 & 39.2 \\
Urinary N, g/d & 48 & 225.4 & 150.0 & & \\
\hline
\end{tabular}

manure excretion estimates of dairy cattle (ASAE, 2001), urine excretion from a $625-\mathrm{kg}$ cow would be 16.3 $\mathrm{kg} / \mathrm{d}$, which was much lower than the average urine excretion in the LACT data set. Urinary excretion estimates from the 2001 ASAE standards were also less than values reported by Broderick (2003), Sannes et al. (2002), and Valadares et al. (1999). Urine excretion values reported by Sannes et al. (2002) and Broderick (2003) ranged from 21.8 to $25.7 \mathrm{~L} / \mathrm{d}$ and from 20.8 to $27.3 \mathrm{~L} / \mathrm{d}$, respectively, and were similar to values in the LACT data set. Valadares et al. (1999) reported greater daily urine excretion, ranging from 31.5 to $50.7 \mathrm{~kg} / \mathrm{d}$ across various dietary treatments.

Dietary CP concentrations have been shown to affect urine excretion (Sannes et al., 2002; Broderick, 2003; Wattiaux and Karg, 2004). An increase in dietary CP concentration from 15.1 to $18.4 \%$ of $\mathrm{DM}$ was associated with increased urine excretion of $6.5 \mathrm{~L} / \mathrm{d}$ (Broderick, 2003). Similarly, Sannes et al. (2002) and Wattiaux and Karg (2004) reported greater urine excretion for high protein diets (19.1 and $17.9 \% \mathrm{CP}$, respectively) compared with low protein diets $(17.2$ and $16.5 \% \mathrm{CP}$, respectively). Conversely, Tomlinson et al. (1996) did not find increases in urine excretion with increasing dietary $\mathrm{CP}$ concentrations from 12 to $18 \% \mathrm{CP}$.

Animal and dietary factors were used as independent variables to determine significant factors for predicting urine excretion in the LACT data set. Factors related to urine excretion $(P<0.01)$ included DMI, NI, BW, MUN, and dietary NDF concentration. Days in milk, MILK, MTP, and MF were also evaluated in the regression equations, but were not related to $(P>0.14)$ urine excretion. In the LACT data set, MUN was the best individual factor for predicting urine excretion [Eq.1] based on the precision of future predictions. Similarly, MUN was determined to be the best factor for predicting urine excretion by Jonker et al. (1998) and Kohn et al. (2002).

$$
\begin{gathered}
\text { Urine excretion, } \mathrm{kg} / \mathrm{d}=[\mathrm{MUN} \times 0.563( \pm 0.115)] \\
+17.1( \pm 2.0)
\end{gathered}
$$

Residual $\mathrm{SE}=5.8$; interstudy $\mathrm{SE}=4.7$.

Body weight and DMI were added to the MUN prediction equation to see if the additional variables improved the prediction of urine excretion. When BW, DMI, and MUN were evaluated, there was a slight reduction in the residual SE, from 5.8 for [1] to 5.5, but there was not any improvement in prediction across studies. An equation for estimating urine excretion with MUN as the only variable provides a simple means by which producers can estimate total urine excretion on their operations.

The VALIDATE data set was used to evaluate [1]. Evaluation of [1] resulted in an average mean bias of $5.26(2.10) \mathrm{kg} / \mathrm{d}$, indicating that the use of [1] for cows in the VALIDATE data set underestimated the urine excretion of these cows by an average of $5.3 \mathrm{~kg} / \mathrm{d}$. However, the error between measurements was greater than the mean bias determined during the evaluation of [1]. The linear bias was not significant $(P=0.85)$, demonstrating that [1] predicted urine excretion evenly across lesser and greater predicted values in the VALIDATE data set.

Effect of Minerals on Urine Excretion. The MINERAL subset was used to predict the effect of mineral intakes and urinary mineral concentrations on urine excretion because the LACT data set did not include mineral analyses. Intakes of $\mathrm{Na}$ and $\mathrm{Cl}$ in the MINERAL subset were closely related $(P<0.01)$ to urine excretion. The intake of $\mathrm{Na}$ and the $\mathrm{N}$ use efficiency, as measured by MUN, were the factors that accounted for the greatest variation within studies (interstudy $\mathrm{SE}$ ) in the MINERAL subset [Eq. 2]. 


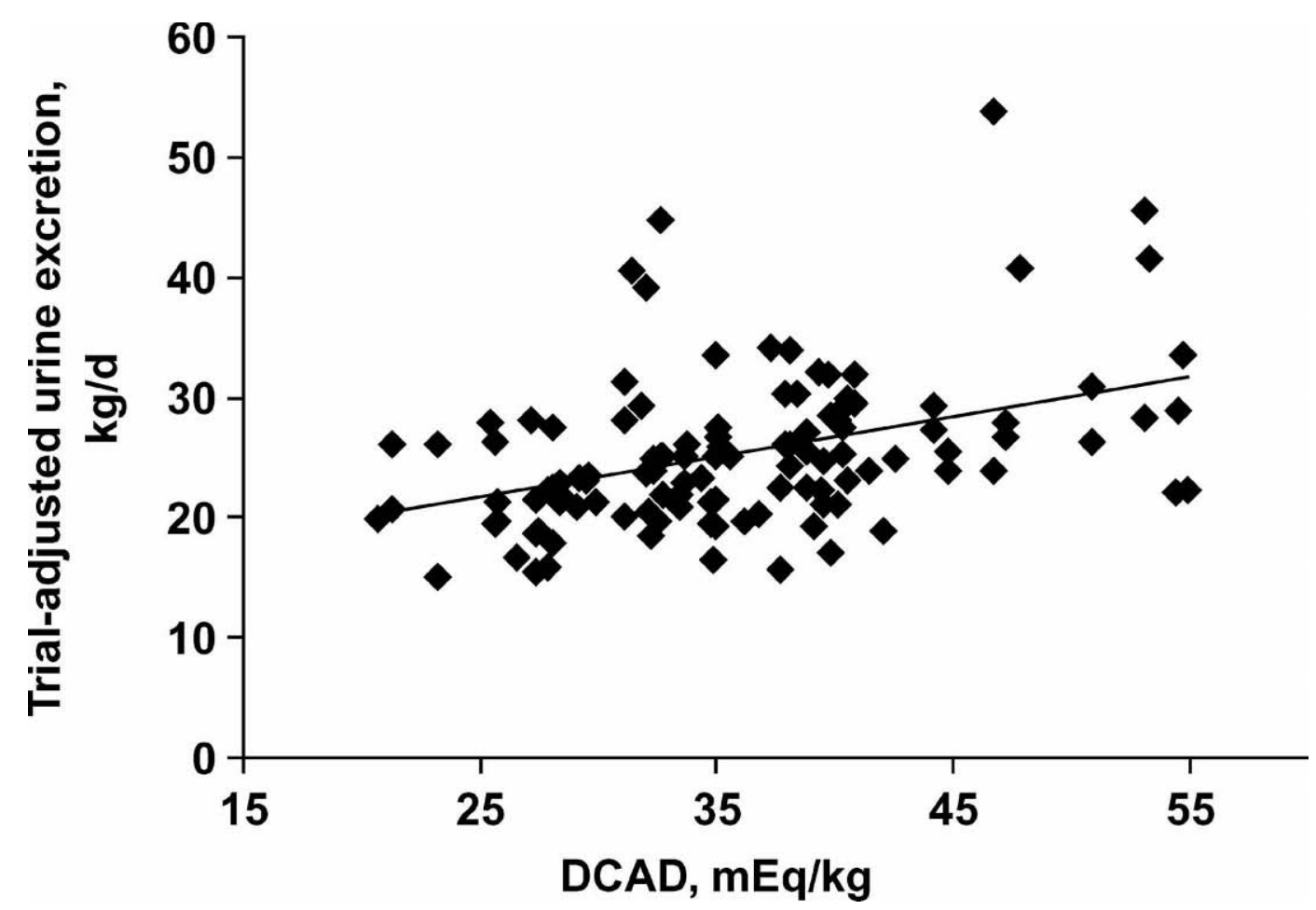

Figure 1. Relationship between DCAD $[(\mathrm{Na}+\mathrm{K})-(\mathrm{S}+\mathrm{Cl})]$ and trial-adjusted urine excretion (kg/d) for lactating cows $(\mathrm{MINERAL}$ subset, $\mathrm{n}=115)$. The solid line is equal to urine excretion $(\mathrm{kg} / \mathrm{d})=(\mathrm{DCAD}, \mathrm{mEq} / \mathrm{kg} \times 0.337)+13.2$, Residual $\mathrm{SE}=6.1$, interstudy $\mathrm{SE}=3.8$.

$$
\begin{gathered}
\text { Urine excretion, } \mathrm{kg} / \mathrm{d}=[\mathrm{NaI} \times 0.062( \pm 0.016)] \\
+[\mathrm{MUN} \times 0.43( \pm 0.21)]+11.4( \pm 3.8)
\end{gathered}
$$

$$
\text { Residual } \mathrm{SE}=5.8 \text {; interstudy } \mathrm{SE}=5.2 \text {. }
$$

When the MINERAL subset was used to develop a simple linear equation with MUN as the only independent variable, the error of future predictions was 8.38 compared with 7.79 for [2]. Therefore, the comparison of [2] with the equation containing only MUN indicated that the precision of estimating urine excretion improved when $\mathrm{NaI}$ and MUN were used as variables for predicting urine excretion. Although $\mathrm{NaI}$ is not commonly available on many dairy operations, future improvements in measurements of intake and dietary mineral composition could increase the possibility of including $\mathrm{NaI}$ as a variable for estimating urine excretion on individual dairy operations.

In the MINERAL subset, there was a relationship ( $P$ $<0.01$ ) between the DCAD and urine excretion (Figure 1). The DCAD was the best single predictor of urine excretion between studies in the MINERAL subset [Eq.3]. Prediction of urine excretion using DCAD was $14.4 \%$ more precise than when MUN was used as the only predictor and $8.0 \%$ more accurate than [2].

$$
\begin{gathered}
\text { Urine excretion, } \mathrm{kg} / \mathrm{d}=[\mathrm{DCAD} \times 0.337( \pm 0.090)] \\
+13.2( \pm 3.6) \\
\text { Residual } \mathrm{SE}=6.1 ; \text { interstudy } \mathrm{SE}=3.8 .
\end{gathered}
$$

The effect of DCAD on urine excretion is not surprising because urinary excretion is the main homeostatic regulation for $\mathrm{Na}, \mathrm{K}$, and $\mathrm{Cl}$ (Miller, 1975; Maltz and Silanikove, 1996). When NI, KI, and NaI were all used as predictors of urine excretion, only $\mathrm{NaI}$ was significant $(P<0.01)$, indicating the $\mathrm{NaI}$ had a greater effect on urine excretion in the MINERAL subset than KI or NI.

Evaluation of $\mathrm{KI}$ as the only variable included for prediction of urine excretion resulted in a positive relationship of $\mathrm{KI}$ to urine excretion $(P<0.12)$. Fisher et al. (1994) also reported that KI had a significant affect on urine excretion, and Bannink et al. (1999) found that KI was significant when included with NaI. Overall, [3] had lower residual and interstudy SE than the equation that only included KI, and would be expected to provide better (more precise) estimates of urine excretion.

Concentrations of minerals in urine and urinary mineral excretion were also evaluated as predictors of urine excretion. Urinary minerals were evaluated to determine if urine excretion was more closely related to uri- 
nary concentrations of minerals or to total mineral excretion. Urine excretion in the MINERAL subset was related to both concentrations of $\mathrm{Na}, \mathrm{K}$, and $\mathrm{S}(P<0.01)$ in the urine and urinary excretions of $\mathrm{N}, \mathrm{K}$, and $\mathrm{Na}(P$ $<0.01)$.

An equation for predicting urine excretion, that included urinary excretion of $\mathrm{N}$ and $\mathrm{Na}$ and the concentration of $\mathrm{K}$ in urine as independent variables, [Eq.4] was developed using the MINERAL subset:

$$
\begin{gathered}
\text { Urine excretion, } \mathrm{kg} / \mathrm{d}=\left[\mathrm{U}_{\mathrm{N}} \times 0.051( \pm 0.014)\right] \\
+\left[\mathrm{U}_{\mathrm{Na}} \times 0.119( \pm 0.024)\right] \\
-[\text { Urinary } \mathrm{K}, \% \times 22.8( \pm 3.2)]+19.8( \pm 3.4) \\
\text { Residual } \mathrm{SE}=4.1 ; \text { interstudy } \mathrm{SE}=5.2 .
\end{gathered}
$$

Equation 4 indicated that the excretion of $U_{N}$ and $\mathrm{U}_{\mathrm{Na}}$ affected the amount of urine excreted by cows in the MINERAL subset more than the concentrations of $\mathrm{N}$ and $\mathrm{Na}$ in urine. Compared with $\mathrm{N}$ and $\mathrm{Na}$, the concentration of $\mathrm{K}$ in urine had a greater effect on urine excretion than did total $\mathrm{U}_{\mathrm{K}}$. The role of $\mathrm{Na}$ and $\mathrm{K}$ in urine excretion could affect the concentration of $\mathrm{N}$ in the urine. Maltz and Silanikove (1996) found an increase in urea concentrations in urine when there were reductions in $\mathrm{Na}, \mathrm{K}$, and $\mathrm{Cl}$ ions. An increase in the urinary $\mathrm{N}$ concentration may affect the rate of ammonia volatilization on a dairy operation.

Equations [2], [3], and [4] could not be evaluated with the VALIDATE data set due to the unavailability of mineral data on cows in the data set. However, the MINERAL data set was used to evaluate previously published equations.

Evaluation of Published Urine Excretion Equations. Presently, few equations for predicting urine excretion for lactating dairy cows are available in the literature. A published equation [(PE) PE1] was proposed by Fox et al. (2004) to predict urine excretion (Table 4). When PE1 was evaluated with the VALIDATE data set, the mean bias was $8.96( \pm 1.10) \mathrm{kg} / \mathrm{d}$ and there was not a significant linear bias $(P=0.40)$. Therefore, PE1 adequately described the lesser and greater predicted values in the VALIDATE data set, but underestimated the average urine excretion.

Evaluation of PE1 with the LACT data set resulted in a linear bias $(P<0.01)$ and a trend $(P<0.07)$ toward a mean bias $(3.28 \mathrm{~kg} / \mathrm{d})$. In the LACT data set, the mean bias for urine excretion was less than the errors between measurements, indicating that PE1 adequately predicted average urine excretion in the LACT data set. The differences between the average values of observed and predicted urine excretions (mean bias) using PE1 may have been caused by the lack of inclusion of terms accounting for $\mathrm{N}$ metabolism or $\mathrm{Na}$ and $\mathrm{K}$ intakes.

In 1999, Bannink et al. developed an equation (PE2) for predicting urine excretion using $\mathrm{NaI}$ and $\mathrm{KI}$ (Table 4). When PE2 was evaluated using the MINERAL subset, there was a linear bias $(-0.69 ; P<0.01)$ and mean bias $(-7.3 \mathrm{~kg} / \mathrm{d} ; P<0.01)$. The standard deviation of the residuals from the evaluation of PE2 was 9.08; thus, the mean bias was less than the expected variation between studies, and the use of PE2 would provide an accurate average excretion value. The linear bias resulted in an overestimation of less than $23 \mathrm{~kg} / \mathrm{d}$ at the maximum predicted urine excretion $(54.6 \mathrm{~kg} / \mathrm{d})$, indicating that PE2 was not accurate across the range of data in the MINERAL subset.

Daily urinary excretions of $\mathrm{N}, \mathrm{Na}$, and $\mathrm{K}$ have been used to predict urine excretion (Bannink et al., 1999). In 1999, Bannink et al. proposed PE3 (Table 4) to predict urine excretion. When PE3 was evaluated using the MINERAL subset, there were mean and linear biases $(P$ $<0.05$ ). When the mean bias was evaluated, the standard error of the residuals was greater than the mean bias. The mean bias, even though it was significant, resulted in an average estimate of urine excretion that was less than the variation expected between studies. The value of the linear bias for the minimum predicted urine excretion of $7.2 \mathrm{~kg} / \mathrm{d}$ was $8.1 \mathrm{~kg} / \mathrm{d}$, slightly greater than the standard error of $6.5 \mathrm{~kg} / \mathrm{d}$. Although PE3 underestimated urinary excretion for cows with lower predicted urinary excretion and overestimated urine excretion for cows with the greatest predicted urinary excretion, it adequately estimated the average urinary excretion for cows in the MINERAL data set.

The final equation evaluated for prediction of urine excretion was developed by Bannink et al. (1999) and combined several factors including mineral intakes, MILK, and MTP (PE4; Table 4). Evaluation of PE4 with the MINERAL subset resulted in mean $(-7.06)$ and linear $(-0.693)$ biases $(P<0.01)$. Similar to the previous equations evaluated, the mean bias, although significant, was less than the variation expected between studies. The linear bias resulted in an estimated urine excretion of less than $23 \mathrm{~kg} / \mathrm{d}$ greater than was observed at the maximum predicted urine excretion $(55.3 \mathrm{~kg} / \mathrm{d})$ and was outside the SE of 8.3 .

\section{Urinary Nitrogen Excretion}

Urinary $\mathrm{N}$ excretion averaged $49 \%$ of total manure $\mathrm{N}$ excretion for dairy cows in the LACT data set. Excess dietary $\mathrm{N}$ is excreted via urine in the form of urea. Urea is a soluble compound that will diffuse to various body fluids, including blood and milk, in the lactating cow (Kauffman and St-Pierre, 2001; Nousiainen et al., 
Table 4. Previously published prediction equations (PE) evaluated using either the LACT data set, VALIDATE data set, or the MINERAL subset

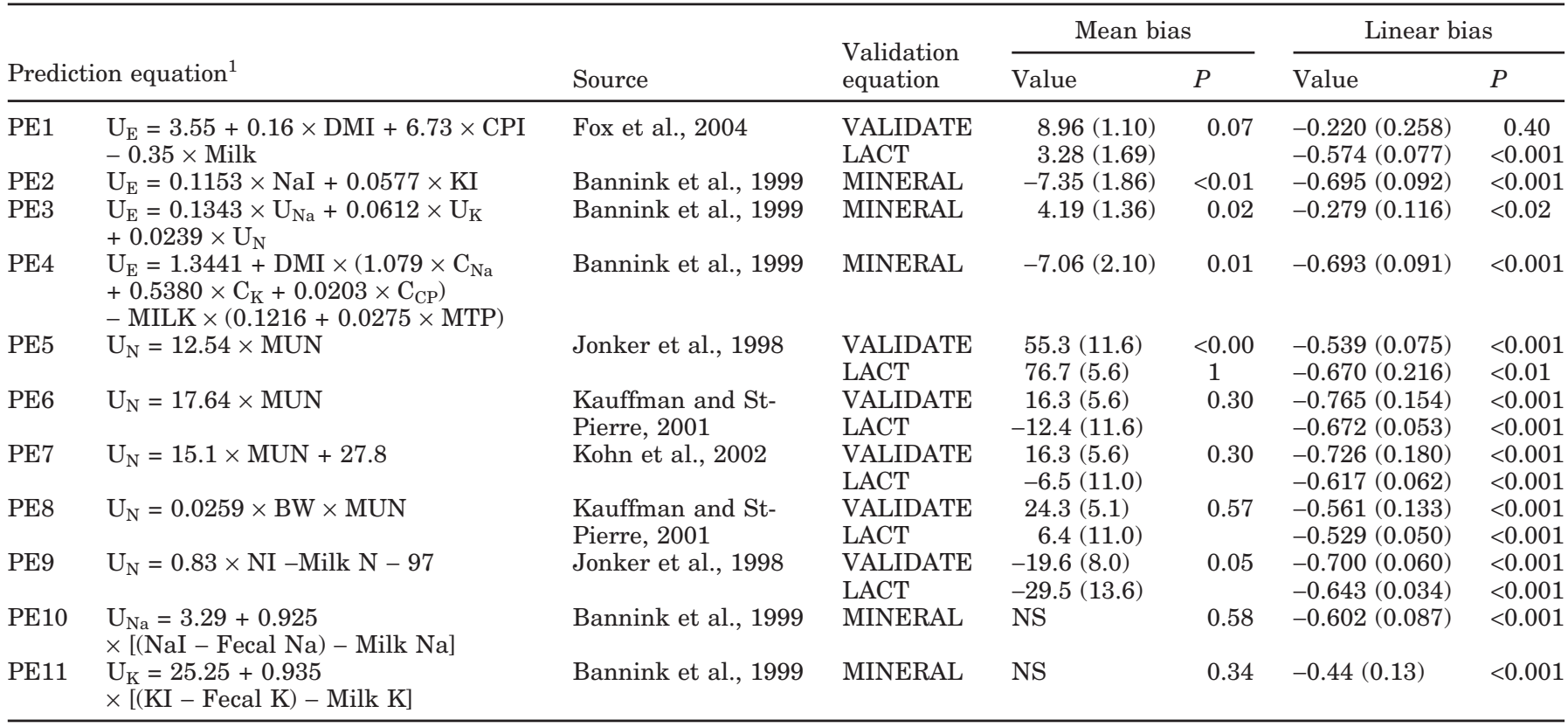

${ }^{1} \mathrm{U}_{\mathrm{E}}=$ Urine excretion, $\mathrm{kg} / \mathrm{d}$; $\mathrm{CPI}=$ crude protein intake, g/d; Milk = milk yield, $\mathrm{kg} / \mathrm{d} ; \mathrm{NaI}=\mathrm{Na}$ intake, g/d; KI = K intake, $\mathrm{g} / \mathrm{d} ; \mathrm{U} \mathrm{Na}=$ urinary $\mathrm{Na}$ excretion, g/d; $U_{\mathrm{K}}=$ urinary $\mathrm{K}$ excretion, g/d; $\mathrm{U}_{\mathrm{N}}=$ urinary $\mathrm{N}$ excretion, $\mathrm{g} / \mathrm{d} ; \mathrm{C}_{\mathrm{Na}}=$ dietary Na concentration, \% of $\mathrm{DM} ; \mathrm{C}_{\mathrm{K}}=$ dietary $\mathrm{K}$ concentration, \% of DM; $\mathrm{C}_{\mathrm{CP}}=$ dietary $\mathrm{CP}$ concentration, \% of DM; MTP = milk true protein, \%; NI = nitrogen intake, g/d; Fecal $\mathrm{Na}=$ fecal $\mathrm{Na}$ excretion, g/d; Milk $\mathrm{Na}=$ milk Na secretion, g/d; Fecal $\mathrm{K}=$ fecal $\mathrm{K}$ excretion, g/d; Milk $\mathrm{K}=$ milk K secretion, g/d.

2004). In addition, the concentration of MUN is directly affected by dietary CP concentrations (Nousiainen et al., 2004). Because excess dietary $\mathrm{N}$ is excreted mostly in the form of urea, MUN would be expected to have a direct effect on $\mathrm{U}_{\mathrm{N}}$. As expected, MUN was positively related to $\mathrm{U}_{\mathrm{N}}(P<0.01)$ in the LACT data set.

Equations for estimating $U_{N}$ were developed using the LACT data set. Independent variables related $(P<$ $0.10)$ to $\mathrm{U}_{\mathrm{N}}$ included BW, NI, DMI, DIM, and MUN. The best individual predictor of $U_{N}$ within studies in the LACT data set was NI. An increase in $U_{N}$ has been associated with greater $\mathrm{N}$ intakes in several studies (Sannes et al., 2002; Broderick, 2003; Wattiaux and Karg, 2004). In 1998, Jonker et al. proposed an equation for predicting $\mathrm{U}_{\mathrm{N}}$ that included NI, and Nousiainen et al. (2004) found that the dietary CP concentration was a better predictor or $\mathrm{U}_{\mathrm{N}}$ than was MUN.

The RDP supply was used to evaluate the relationships between protein type and $\mathrm{U}_{\mathrm{N}}$. The best simple linear equation [Eq. 5] for predicting $U_{N}$ both within and between studies in the LACT data set included RDP supply as determined by the 2001 NRC model (Figure 2).

$$
\begin{gathered}
\mathrm{U}_{\mathrm{N}}=[\mathrm{RDP} \times 0.0628( \pm 0.00064)]+55.6( \pm 19.1) \\
\text { Residual } \mathrm{SE}=42.8 ; \text { interstudy } \mathrm{SE}=35.4
\end{gathered}
$$

Multiple regression equations were also evaluated for the prediction of $U_{N}$ [Eq. 6].

$$
\begin{gathered}
\mathrm{U}_{\mathrm{N}}=[\mathrm{BW} \times 0.254( \pm 0.039)]-[\mathrm{MILK} \times 1.03( \pm 0.40)] \\
+[\mathrm{NI} \times 0.2101( \pm 0.0278)]+[\mathrm{MUN} \times 5.09( \pm 0.787)] \\
+[\mathrm{MTP} \times 21.8( \pm 8.3)]-[\mathrm{MF} \times 6.5( \pm 3.5)] \\
-138.8( \pm 44.0)
\end{gathered}
$$$$
\text { Residual SE = 38.6; interstudy } \mathrm{SE}=46.4 \text {. }
$$

Although the multiple regression equation [Eq. 6] decreased the variation within studies, the multiple linear regression equation did not significantly improve the prediction of $\mathrm{U}_{\mathrm{N}}$ across studies. The errors associated with each of the independent variables in the multiple linear regression equation would also decrease the preciseness of the prediction of urinary $\mathrm{N}$ excretion.

Equation [5], the best equation for the prediction of $\mathrm{U}_{\mathrm{N}}$ in the LACT data set, was evaluated using the VALIDATE data set. Evaluation of [5] with the VALIDATE data set did not result in a linear bias $(P=0.90)$, and the mean bias was only $9.6( \pm 4.5) \mathrm{g} / \mathrm{d}$ and was less than the standard deviation of the residuals. The lack of biases during the evaluation of [5] indicated that this equation was an accurate estimator of urinary N excretion for cows in the VALIDATE data set. 


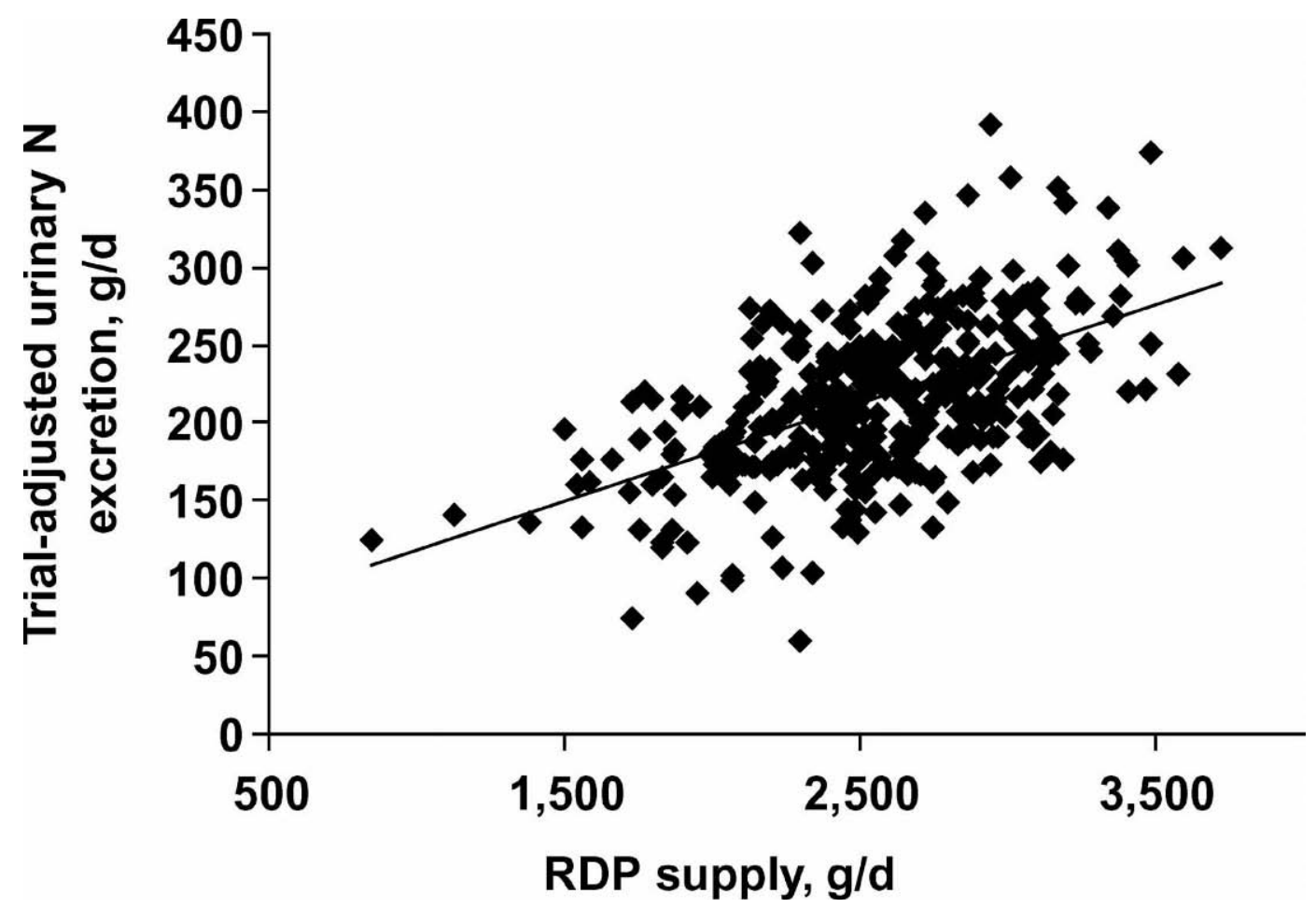

Figure 2. Relationship between the rumen-degradable protein supply (g/d) as calculated by the 2001 NRC model and trial-adjusted urinary $\mathrm{N}$ excretion $(\mathrm{g} / \mathrm{d})$ for lactating cows (LACT data set, $\mathrm{n}=372)$. The solid line is equal to urinary $\mathrm{N}$ excretion $(\mathrm{g} / \mathrm{d})=(\mathrm{RDP}$ supply, $\mathrm{g} /$ $\mathrm{d} \times 0.0628)+55.6$, Residual $\mathrm{SE}=42.8$, interstudy $\mathrm{SE}=35.4$

When equation 6 was evaluated using the VALIDATE data set, there was no linear bias $(P=0.22)$ and the average mean bias was $43.86( \pm 4.20)$. Although multiple regression equations such as [6] may provide insights into animal metabolism, these equations are often not practical for application on dairy operations.

Evaluation of Published Urinary Nitrogen Excretion Equations. Numerous equations have been proposed to predict $U_{\mathrm{N}}$ from lactating dairy cows (Table 4). Many of these previously published prediction equations have included MUN in the equation because equilibration of urea in the body results in a direct relationship to $\mathrm{U}_{\mathrm{N}}$ (Kauffman and St-Pierre, 2001; Nousiainen et al., 2004). An additional advantage of the use of MUN as an independent variable for prediction of $U_{N}$ is the ease and low cost of determining MUN. The challenge of using MUN as an independent variable is a result of the differences in the calibration and accuracy of the laboratory equipment used to determine the MUN values for many commercial dairy operations (Kohn et al., 2004).

Previously published equations for predicting $U_{N}$ have been evaluated by several researchers (Kauffman and St-Pierre, 2001; Kohn et al., 2002; Nousiainen et al., 2004). Besides evaluation of equations, several of these researchers proposed additional equations for prediction of $\mathrm{U}_{\mathrm{N}}$. Evaluation of previously published equations provides information as to the usefulness of the prediction equations in various dietary and management situations.

Jonker et al. (1998) proposed the use of PE5 to predict $\mathrm{U}_{\mathrm{N}}$. In 2001, Kauffman and St-Pierre reported that the coefficient (12.54) from PE5 should be increased to 17.6 to account for an inaccuracy in the determination of the equipment used for calculation of MUN values. The adjustment in MUN values was confirmed by Kohn et al. (2002). When PE5 was evaluated using both the LACT and VALIDATE data sets, there were mean biases $(P<0.01)$ of 76.7 and $55.3 \mathrm{~g} / \mathrm{d}$, respectively, which further confirmed the need for an adjustment to the coefficient of the MUN term in PE5 (Jonker et al., 1998).

Another equation for predicting $U_{N}$ using adjusted MUN values was published by Kauffman and St-Pierre (2001). When PE6 was evaluated with the LACT data set, there was not a mean bias $(P=0.30)$, but there was a linear bias $(-0.672 ; P<0.01)$. The linear bias resulted in a maximum bias of $175 \mathrm{~g} / \mathrm{d}$ over the entire range of the predicted values.

In 2002, Kohn et al. evaluated equations published by Jonker et al. (1998) and Kauffman and St-Pierre (2001) and proposed an additional equation for prediction of $\mathrm{U}_{\mathrm{N}}$ (PE7). Evaluation of PE7 with the LACT 


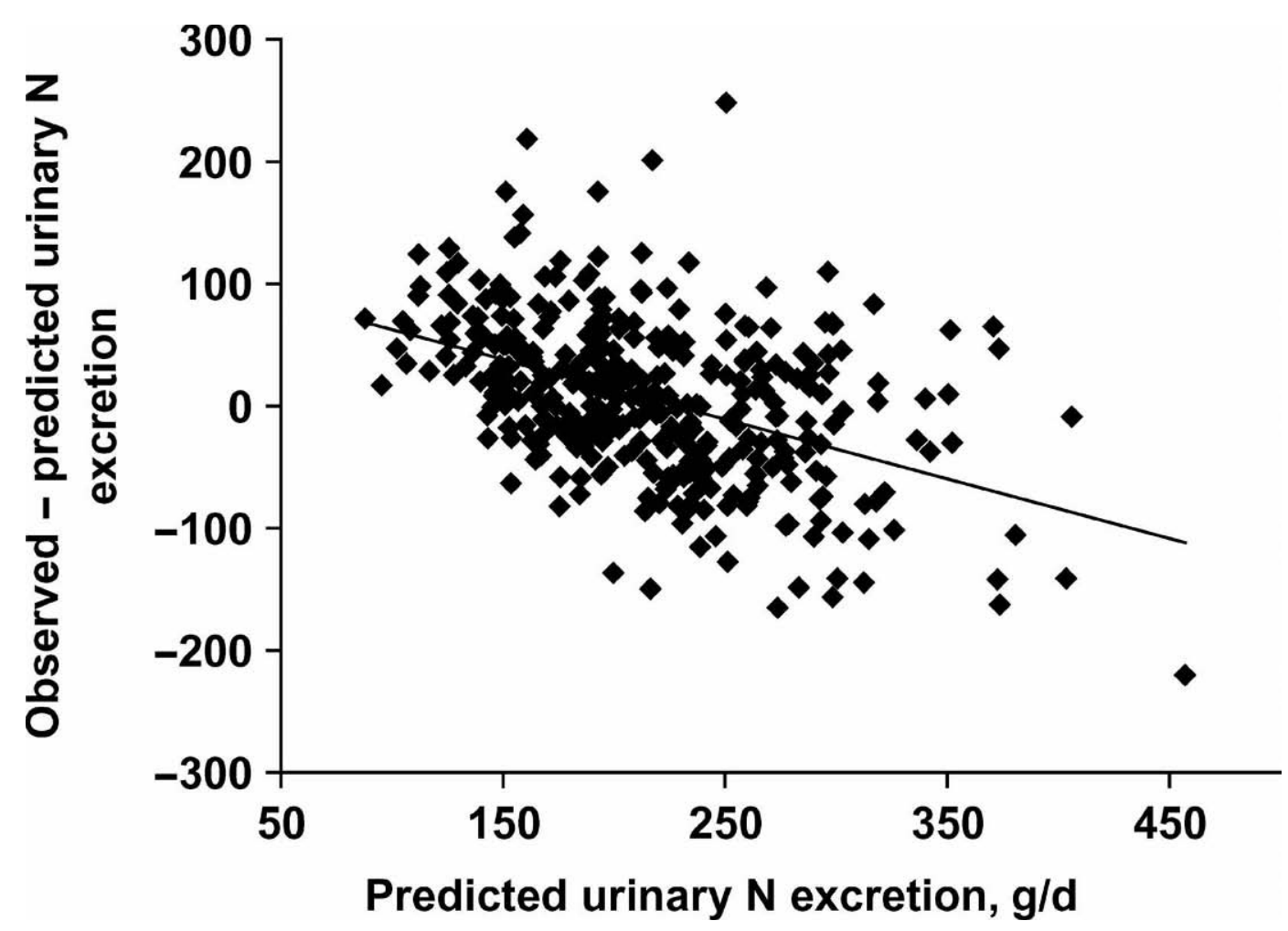

Figure 3. Plot of residuals (observed - predicted) vs. predicted values of urinary N excretion (g/d) from evaluation of the equation [urinary $\mathrm{N}, \mathrm{g} / \mathrm{d}=(0.0259 \times \mathrm{BW}, \mathrm{kg} \times \mathrm{MUN}, \mathrm{mg} / \mathrm{dL})]$ by Kauffman and St-Pierre, 2001. The equation was evaluated using the LACT data set. The solid line on the graph represents the equation $\mathrm{y}=6.40( \pm 11.04)-0.529( \pm 0.050)(\mathrm{x}-216)$. Evaluation of the equation did not result in a mean bias. The linear bias was significant $(-0.529 ; P<0.01)$.

data set resulted in a linear bias of $-0.617(P<0.01)$. Equation PE7 was comparable to PE6 for prediction of $\mathrm{U}_{\mathrm{N}}$ in the LACT and VALIDATE data sets, with a maximum bias of $135 \mathrm{~g} / \mathrm{d}$ over the full range of the data.

Prediction equations for $U_{N}$ were developed for both Holsteins and Jerseys by Kauffman and St-Pierre (2001). The development of prediction equations across breeds led to an adjustment for $\mathrm{BW}$ in the $\mathrm{U}_{\mathrm{N}}$ prediction equation. Evaluation of PE8 with the LACT data set did not result in a mean bias, but there was a linear bias $(P<0.01)$ of -0.529 (Figure 3$)$. The maximum bias for PE8 was less than $122 \mathrm{~g} / \mathrm{d}$ over the range of the predicted values and resulted in the least bias of the equations evaluated for prediction of $U_{N}$. When the VALIDATE data set was used to evaluate PE8, the mean bias was less than the standard deviation of the residuals, and the linear bias for the minimum predicted value $(129.6 \mathrm{~g} / \mathrm{d})$ was less than $65 \mathrm{~g} / \mathrm{d}$. Equation PE8, by Kauffman and St-Pierre (2001), was designed to be applicable across breeds and provides a means of determining the effects of MUN values on $U_{N}$.

An additional equation, that included NI as an independent variable, was proposed by Jonker et al. (1998). When PE9 was evaluated using the LACT data set, there was a mean bias $(29.5 ; P<0.05)$, but the bias was less than the variation between the residuals. The linear bias $(-0.643 ; P<0.01)$ resulted in a maximum bias of $192 \mathrm{~g} / \mathrm{d}$ from the least to the greatest predicted values when PE9 was evaluated with the LACT data set. Evaluation of PE9 with the VALIDATE data set resulted in a mean bias $(-19.6 \mathrm{~g} / \mathrm{d})$ that was also less than the standard deviation of the residuals, but there was still a significant linear bias $(-0.700 ; P<0.01)$. The linear bias resulted in an overestimation of approximately $143 \mathrm{~g} / \mathrm{d}$ at the maximum predicted value of 420.8 $\mathrm{g} / \mathrm{d}$ in the VALIDATE data set. The greatest difficulty with PE9 occurred when early lactation cows were evaluated using the equation. The use of PE9 resulted in negative prediction values for early lactation animals. The negative predictions were most likely a result of the negative $\mathrm{N}$ balance of these early lactation cows, and indicated that PE9 should not be used for cows in early lactation. An additional challenge for using PE9 is that the equation requires a value for NI, which may not be known on many dairy operations. If NI is not available on a dairy operation, PE8 could be used for predicting $\mathrm{U}_{\mathrm{N}}$, as this equation resulted in the least amount of bias over the range of the data evaluated. 
An additional advantage of PE8 is the inclusion of $\mathrm{BW}$ in the equation to account for breed differences.

\section{Urinary Mineral Excretion}

Sodium. Average $\mathrm{U}_{\mathrm{Na}}$ in the MINERAL subset was $84.8 \mathrm{~g} / \mathrm{d}$ (Table 3), and accounted for $71.4 \%$ of total $\mathrm{Na}$ excretion. Silanikove et al. (1997) reported that $65 \%$ of total $\mathrm{Na}$ excretion was via urine and Bannink et al. (1999) found $U_{\mathrm{Na}}$ accounted for $76 \%$ of total Na excretion. In the MINERAL subset, the dietary Na concentration was above animal requirements due to the addition of sodium bicarbonate to the diets, thus resulting in greater urinary sodium concentration in the MINERAL subset than reported by Bannink et al. (1999), Shalit et al. (1991), and Tucker et al. (1988).

Urinary $\mathrm{Na}$ excretion was directly related to $\mathrm{NaI}$ in the MINERAL subset as it was in the study reported by Bannink et al. (1999). Equation 7 was developed to estimate $\mathrm{U}_{\mathrm{Na}}$ based on $\mathrm{NaI}$ :

$$
\begin{aligned}
& \mathrm{U}_{\mathrm{Na}}=[\mathrm{NaI} \times 0.456( \pm 0.072)]+26.6( \pm 12.1) \\
& \text { Residual } \mathrm{SE}=20.0 ; \text { interstudy } \mathrm{SE}=18.5 .
\end{aligned}
$$

Urinary Na excretion has also been estimated by the difference in apparently digested $\mathrm{Na}$ and $\mathrm{Na}$ secreted in milk (Bannink et al., 1999). However, the use of apparently digested $\mathrm{Na}$ to determine $\mathrm{Na}$ excretion may not always be accurate due to $\mathrm{Na}$ recycling that occurs for ruminant animals, especially during periods of low $\mathrm{NaI}$ (NRC, 2001).

Potassium. Dietary concentrations of $\mathrm{K}$ in the MINERAL subset averaged $1.34 \%$ of DM, lower than the dietary $\mathrm{K}$ concentrations in many modern dairy diets due to high $\mathrm{K}$ levels in forages. The lower dietary $\mathrm{K}$ concentration in the MINERAL subset resulted in KI that were $26 \%$ less than reported by Bannink et al. (1999). Fisher et al. (1994) reported $U_{K}$ of $209 \mathrm{~g} / \mathrm{d}$ for diets containing $1.6 \% \mathrm{~K}$. The lesser $\mathrm{KI}$ in our study resulted in approximately $50 \%$ of the $\mathrm{U}_{\mathrm{K}}$ reported by Bannink et al. (1999), and in lower concentrations of $\mathrm{K}$ in urine than reported by Shalit et al. (1991). In contrast, Tucker et al. (1988) reported urinary K concentrations that were similar to concentrations in our data set when the dietary concentration of $(\mathrm{Na}+\mathrm{K})-$ $\mathrm{Cl}$ equaled $10 \mathrm{mEq} / 100 \mathrm{~g}$ of diet $\mathrm{DM}$ in their study.

Increased $\mathrm{KI}$ resulted in greater $\mathrm{U}_{\mathrm{K}}$ in the MINERAL subset [Eq. 8].

$$
\begin{gathered}
\mathrm{U}_{\mathrm{K}}=[\mathrm{KI} \times 0.451( \pm 0.092)]+40.2( \pm 29.9) \\
\text { Residual SE }=38.8 ; \text { interstudy SE }=41.6 .
\end{gathered}
$$

In the MINERAL subset, $75 \%$ of K excretion occurred via urinary routes. Conversely, Silanikove et al. (1997) reported that $\sim 64 \%$ of $\mathrm{K}$ excreted in manure was through urinary excretion, and Bannink et al. (1999) found that urinary excretion accounted for over $87 \%$ of total K excretion.

Evaluation of Published Urinary Na and K Excretion Equations. Equation PE10 was proposed in 1999 by Bannink et al. to estimate $\mathrm{U}_{\mathrm{Na}}$ (Table 4). When PE10 was evaluated using the MINERAL subset, the linear bias $(P<0.01)$ was less than $66 \mathrm{~g} / \mathrm{d}$ over the range of predicted values. The mean bias was not significant $(P=0.58)$ and estimated the average $\mathrm{U}_{\mathrm{Na}}$ of the cows in the MINERAL subset.

Bannink et al. (1999) proposed an equation to estimate $U_{K}(P E 11$; Table 4) that required an estimation of apparently digested $\mathrm{K}$. There was not a mean bias when PE11 was evaluated using the MINERAL subset, but there was a linear bias $(P<0.01)$. The linear bias was less than $87 \mathrm{~g} / \mathrm{d}$ for the maximum predicted value of $339.4 \mathrm{~g} / \mathrm{d}$. However, the amount of apparently digested $\mathrm{K}$ is not an easily obtainable value in practical situations and PE11 would not be practical for use on an on-farm basis.

\section{CONCLUSIONS}

Prediction of urine and urinary $\mathrm{N}$ excretion is related closely to protein metabolism of lactating cows. Crude protein intake and MUN were directly related to both urine and urinary $\mathrm{N}$ excretion in our data set. Inclusion of mineral intake parameters for the prediction of urine excretion resulted in direct relationships between intakes of $\mathrm{Na}$ and $\mathrm{K}$ and excretion of urine. Sodium intake affected urine excretion to a greater extent than did intakes of $\mathrm{N}$ or $\mathrm{K}$. Intake of $\mathrm{N}, \mathrm{Na}$, and $\mathrm{K}$ directly affected urinary excretion of $\mathrm{N}, \mathrm{Na}$, and $\mathrm{K}$, respectively. Evaluation and validation of prediction equations is important to develop equations that will more accurately estimate urine, urinary $\mathrm{N}$, and urinary mineral excretion from lactating dairy cows.

\section{REFERENCES}

American Society of Agriculture Engineers. 2001. Manure production and characteristics. ASAE Standards D384.1. ASAE, St. Joseph, MI.

Bannink, A., H. Valk, and A. M. Van Vuuren. 1999. Intake and excretion of sodium, potassium, and nitrogen and the effects on urine production by lactating dairy cows. J. Dairy Sci. 82:1008-1018.

Broderick, G. A. 2003. Effects of varying dietary protein and energy levels on the production of lactating dairy cows. J. Dairy Sci. 86:1370-1381.

Fisher, L. J., N. Dinn, R. M. Tait, and J. A. Shelford. 1994. Effect of level of dietary potassium on the absorption and excretion of calcium and magnesium by lactating cows. Can. J. Anim. Sci. 74:503-509.

Fox, D. G., L. O. Tedeschi, T. P. Tylutki, J. B. Russell, M. E. Van Amburgh, L. E. Chase, A. N. Pell, and T. R. Overton. 2004. The 
Cornell Net Carbohydrate and Protein System model for evaluating herd nutrition and nutrient excretion. Anim. Feed Sci. Technol. 112:29-78.

Harrison, J., P. Huhtanen, and M. Collins. 2003. Perennial grasses. Pages 665-745 in Silage Science and Technology. D. R. Buxton, R. E. Muck, and J. H. Harrison, ed. ASA-CSSA-SSSA, Madison, WI.

Johnson, L. M., J. H. Harrison, and R. E. Riley. 1998. Estimation of the flow of microbial nitrogen to the duodenum using urinary uric acid or allantoin. J. Dairy Sci. 81:2406-2420.

Jonker, J. S., R. A. Kohn, and R. A. Erdman. 1998. Using milk urea nitrogen to predict nitrogen excretion and utilization efficiency in lactating dairy cows. J. Dairy Sci. 81:2681-2692.

Kauffman, A. J., and N. R. St-Pierre. 2001. The relationship of milk urea nitrogen to urine nitrogen excretion in Holstein and Jersey cows. J. Dairy Sci. 84:2284-2294.

Kohn, R. A., K. R. French, and E. Russek-Cohen. 2004. A comparison of instruments and laboratories used to measure milk urea nitrogen in bulk-tank milk samples. J. Dairy Sci. 87:1848-1853.

Kohn, R. A., K. F. Kalscheur, and E. Russek-Cohen. 2002. Evaluation of models to estimate urinary nitrogen and expected milk urea nitrogen. J. Dairy Sci. 85:227-233.

Mackle, T. R., D. A. Dwyer, K. L. Ingvartsen, P. Y. Chouinard, J. M. Lynch, D. M. Barbano, and D. E. Bauman. 1999. Effects of insulin and amino acids on milk protein concentration and yield from dairy cows. J. Dairy Sci. 82:1512-1524.

Maltz, E., and N. Silanikove. 1996. Kidney function and nitrogen balance of high yielding dairy cows at the onset of lactation. J. Dairy Sci. 79:1621-1626.

Miller, W. J. 1975. New concepts and developments in metabolism and homeostasis of inorganic elements in dairy cattle. A review. J. Dairy Sci. 58:1549-1560.

National Research Council. 2001. Nutrient Requirements of Dairy Cattle. 7th rev. ed. Natl. Acad. Sci., Washington, DC.

Natural Resources Conservation Service. 2001. Nutrient management. Natural Resources Conservation Service Conservation Practice Standard Code 590-1. USDA-NRCS. Spokane, WA.
Nousiainen, J., K. J. Shingfield, and P. Huhtanen. 2004. Evaluation of milk urea nitrogen as a diagnostic of protein feeding. J. Dairy Sci. 87:386-398.

Sannes, R. A., M. A. Massman, and D. B. Vagnon. 2002. Form of rumen-degradable carbohydrate and nitrogen on microbial protein synthesis and protein efficiency of dairy cows. J. Dairy Sci. 85:900-908.

SAS Institute. 1999. SAS User's Guide. Statistics, Version 8.2. SAS Inst., Inc., Cary, NC.

Shalit, U., E. Maltz, and N. Silanikove. 1991. Water, sodium, potassium, and chlorine metabolism of dairy cows at the onset of lactation in hot weather. J. Dairy Sci. 74:1874-1883.

Silanikove, N., E. Maltz, A. Halevi, and D. Shinder. 1997. Metabolism of water sodium, potassium, and chlorine by high yielding dairy cows at the onset of lactation. J. Dairy Sci. 80:949-956.

St-Pierre, N. R. 2001. Integrating quantitative findings from multiple studies using mixed model methodology. J. Dairy Sci. 84:741-755.

St-Pierre, N. R. 2003. Reassessment of biases in predicted nitrogen flows to the duodenum by NRC 2001. J. Dairy Sci. 86:344-350.

Timmermans, S. J., Jr., L. M. Johnson, J. H. Harrison, and D. Davidson. 2000. Estimation of the flow of microbial nitrogen to the duodenum using milk uric acid or allantoin. J. Dairy Sci. 83:1286-1299.

Tomlinson, A. P., W. J. Powers, H. H. Van Horn, R. A. Nordstedt, and C. J. Wilcox. 1996. Dietary protein effects on nitrogen excretion and manure characteristics of lactating cows. Trans. ASAE 39:1441-1448.

Tucker, W. B., G. A. Harrison, and R. W. Hemken. 1988. Influence of dietary cation-anion balance on milk, blood, urine, and rumen fluid in lactating dairy cows. J. Dairy Sci. 71:346-354.

Valadares, R. F. D., G. A. Broderick, S. C. Valadares Filho, and M. K. Clayton. 1999. Effect of replacing alfalfa silage with high moisture corn on ruminal protein synthesis estimated from excretion of total purine derivatives. J. Dairy Sci. 82:2686-2696.

Wattiaux, M. A., and K. L. Karg. 2004. Protein level for alfalfa and corn silage-based diets: II. Nitrogen balance and manure characteristics. J. Dairy Sci. 87:3492-3502. 